\title{
STAGE 3A ENVIRONMENTAL COMPLIANCE OF THE 6-CYLINDER TRACTOR ENGINE
}

\author{
Kukharonak H. ${ }^{1}$, Petruchenko A. ${ }^{2}$, Predko A. ${ }^{2}$, Telyuk D. ${ }^{2}$ \\ ${ }^{1}$ Belarussian National Technical University, Belarus \\ ${ }^{2}$ The OJSC “Minsk Motor Plant” Holding Managing Company, Belarus
}

\begin{abstract}
Problem. The development strategy of the Minsk Motor Plant, implemented within the framework of plant and state scientific and technical programs, is aimed at producing competitive products that meet modern technical requirements of international standards and quality. The mandatory requirement for the successful promotion of diesel engines on the off-road vehicle market is to ensure the required environmental performance, with low fuel consumption and low engine cost. The well-known technical solutions aimed to achieve environmental indicators of the Stage 3A level significantly increase the cost of diesel engines, therefore, the achievement of the required environmental standards without a significant increase in the cost of engines can be considered an urgent task. Purpose. Stage3A Environmental Compliance for 6 Cylinder Tractor Diesel. Methodology. Experimental studies were carried out for diesel engines equipped with: a Common Rail BOSCH accumulator fuel supply system with an injection pressure of $140 \mathrm{MPa}$, injectors with 7 nozzle holes; a direct-action fuel supply system with a MOTORPAL fuel pump providing a maximum injection pressure of $100 \mathrm{MPa}$, MOTORPAL injectors and AZPI with five nozzle holes; combustion chambers of two types with bowl diameters of 55 and $67.5 \mathrm{~mm}$; cylinder heads providing swirl ratios 3-4 and 3.5-4.5; high pressure exhaust gas recirculation system. The tests were carried out at characteristic points of the NRSC cycle at three crankshaft speeds: minimum idle speed $800 \mathrm{~min}^{-1}$, maximum torque $1600 \mathrm{~min}^{-1}$, and maximum power $2100 \mathrm{~min}^{-1}$. Results. It turned out that it is possible to achieve Stage3A emissions standards on $116 \mathrm{~kW}$ diesel engines using direct fuel equipment and a semi-open combustion chamber, on $156 \mathrm{~kW}$ diesel engines using a Low Cost Common Rail fuel supply system and an open combustion chamber. Originality. The results of the combustion chamber shape choice, the parameters of the fuel-injection equipment, the swirl ratio of the inlet channels, valve timings and parameters of the exhaust gas recirculation system made it possible to organize diesel engine workflow of the Stage 3A ecological level. Practical significance. Construction elements of the six-cylinder diesel engines have been developed and introduced at the Minsk Motor Plant.
\end{abstract}

Key words: diesel, swirl ratio, combustion chamber, fuel supply system, injector nozzle.

\section{Introduction}

Diesel engine building is one of the main areas of mechanical engineering that has been developed recently in the Republic of Belarus. Minsk Motor Plant is the oldest enterprise in the Republic that has been producing multi-purpose diesel engines in a wide power range (Fig. 1) [1] for more than 55 years. The development strategy of the enterprise, implemented within the framework of plant and state scientific and technical programs, is aimed at producing competitive products that meet modern technical requirements of international standards and quality [2]. The Technical Regulations of the Customs Union [3], focused on the norms of the UNECE Regulations [4], establishes for diesel engines, newly manufactured or imported new tractors compliance with Stage 3A environmental standards, which should increase the demand for diesel engines of this ecological class $[5,6]$.
Marketing research shows that in the nearest future two modifications of six-cylinder tractor diesel engines D-260.1S3A with a power of $116 \mathrm{~kW}$ and D-260.4S3A with a power of $156 \mathrm{~kW}$ will be in demand.

\section{Analysis of publications}

Achievement of environmental performance of the Stage 3A level is carried out mainly due to the coordination of the shape of the combustion chamber $[7,8]$, the parameters of the fuel supply equipment $[9,10]$, the swirl ratio of the inlet ports $[8,11]$, the valve timing $[10]$ and the use of exhaust gas recirculation (EGR) [10,11].

\section{Theoretical research}

The D-260 engines use cylinder heads with two valves per cylinder, which should ensure the simplicity of the design and maintenance of the gas distribution mechanism. The slightly in- 
creased resistance of the gas exchange channels is to some extent compensated by the engine boost. The inlet channels are dual-function screw. When profiling the channels, the correctness of the adopted design solutions is checked by the method of 3D-modeling of the gas flow (Fig. 2) with the determination of the air flow rate and the mean rotation velocity of the air charge at the given pressure drops [12]. The mathematical model of the flow of a viscous heat-conducting fluid, widely used in solving engineering problems $[13,14,15]$, is based on the Navier - Stokes system of equations, which combines the laws of conservation of mass, momentum and energy of a fluid in a nonstationary setting $[16,17]$.

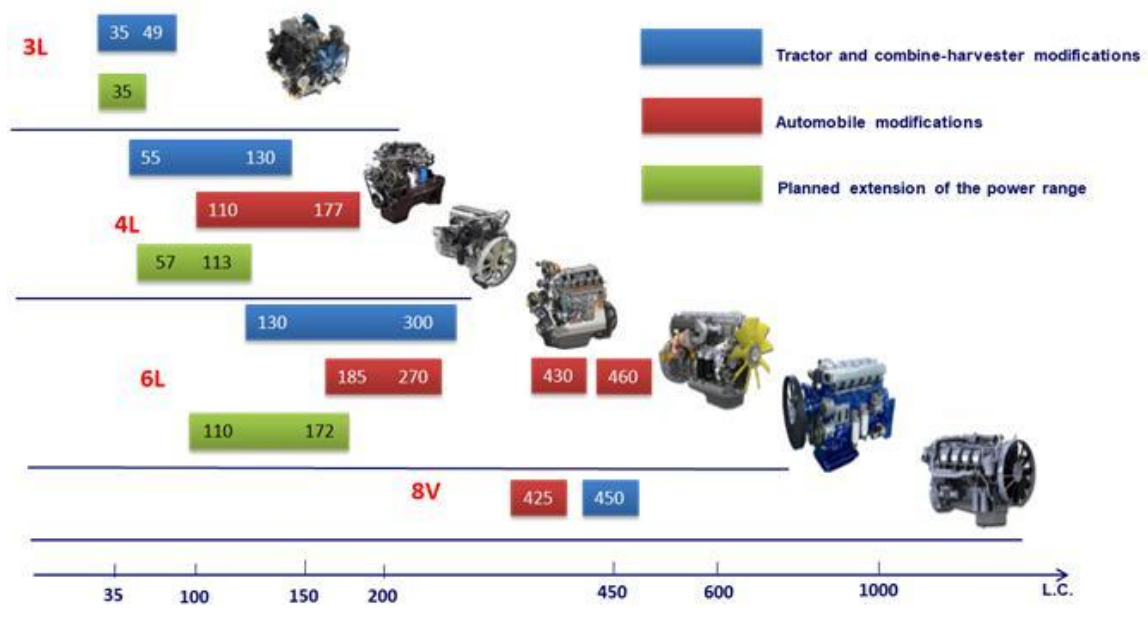

a

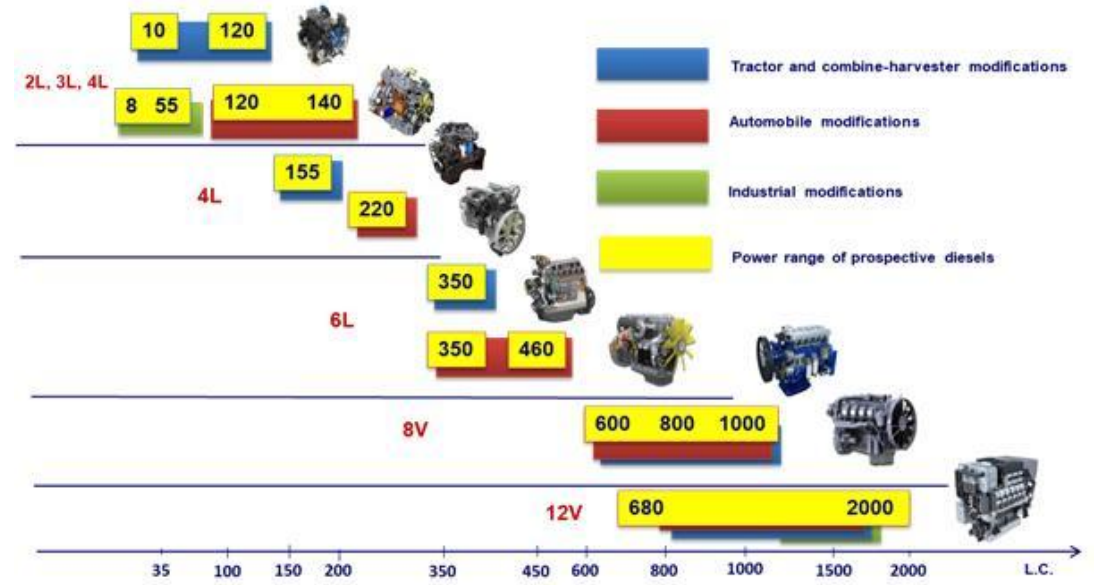

b

Fig. 1. Power range of the engines manufactured by MMP: a) serial engines [1]; b) promising
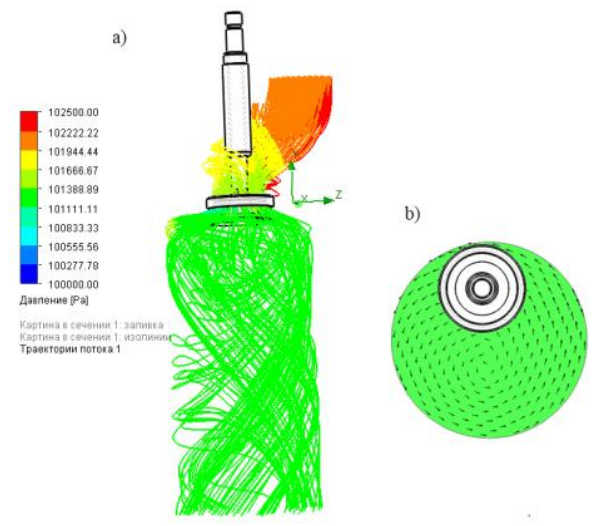

Fig. 2. Results of the inlet channel virtual purge: $\mathrm{a}$ - pressure distribution; $\mathrm{b}$ - velocity field in the outlet section
To control the parameters of the inlet channels of the cast heads, a motorless blow off stand with a straightening grid is used $[12,18]$. Usually, the data of virtual and full-scale blow off differ by no more than $5 \%$. For D-260 engines, head designs have been developed that ensure the generation of an air swirl at the inlet with a swirl ratio of 3-4 and 3.5-4.5.

Heads with a lower swirl ratio are used on engines equipped with accumulator fuel systems with high injection rates and open combustion chambers (Fig. 3.a) [19, 20]. Large swirl ratios are used for engines with direct-action fuel equipment and a semi-open combustion chamber (Fig. 3.b) [21]. 
Serially produced six-cylinder diesel engines D-260, which meet Stage 3A environmental standards, are equipped with fuel supply equipment with electronic control "Common Rail" manufactured by "Bosch"; pistons with an open combustion chamber; a cylinder head with a screw inlet channel providing a swirl ratio

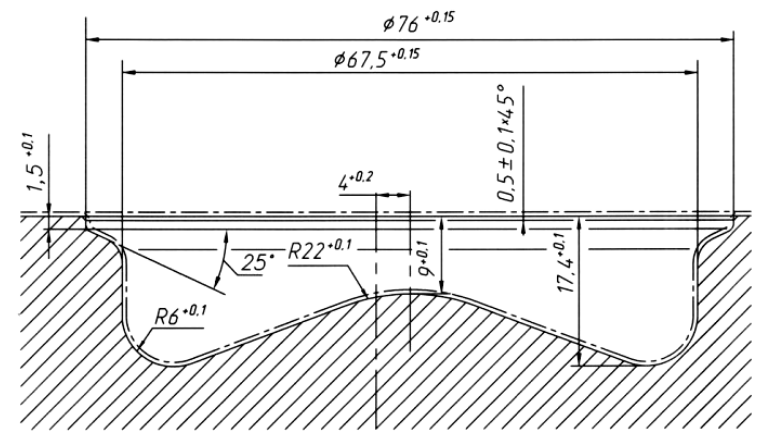

$\mathrm{H}=3-4$; unregulated turbocharging. Low pressure EGR is used to reduce NOx emissions [22].

In order to increase the competitive attractiveness of six-cylinder engines, it was decided to use fuel supply systems of a lower price category - a fuel supply system with a direct-action pump and a mechanical regulator manufactured by Motorpal.

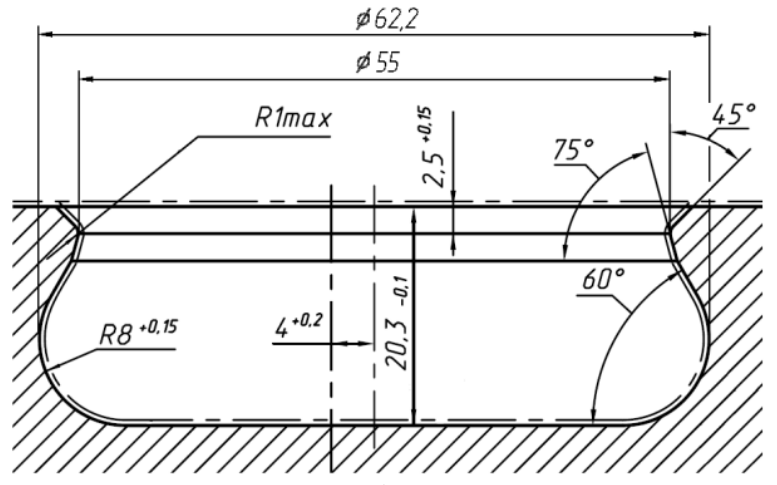

b

Fig. 3. Combustion chambers: $\mathrm{a}$ - open combustion chamber; $\mathrm{b}$ - semi-open combustion chamber

The fuel supply system layout with a directacting pump is shown in Fig. 4.

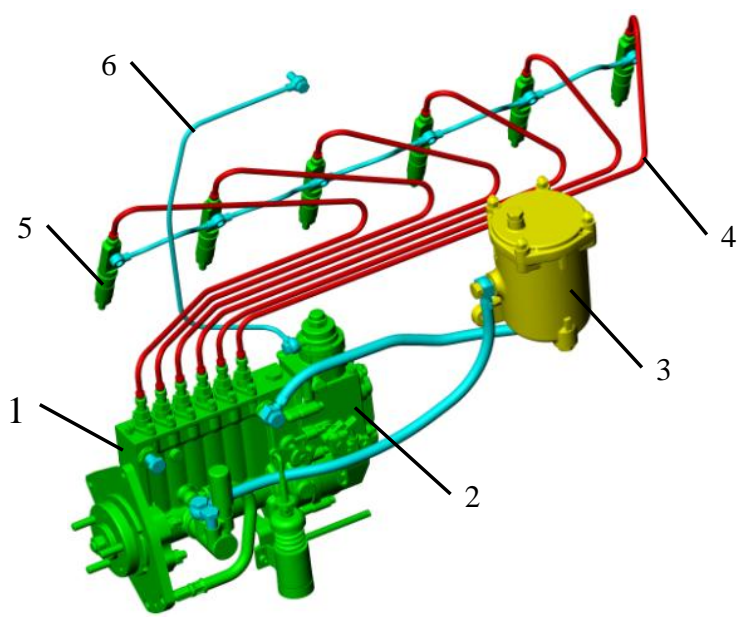

Fig. 4. Fuel supply system layout with a Motorpal pump: 1 - high pressure fuel pump; 2 - speed governor; 3 - fuel filter; 4 - high pressure fuel line; 5 -injector; 6 - tube to the corrector for charge air pressure

The fuel pump 6M4330ZT (Motorpal, Czech Republic) with a diameter of $10 \mathrm{~mm}$ and a plunger stroke of $14 \mathrm{~mm}$ is equipped with a mechanical governor and a fuel supply corrector by the charge air pressure. The maximum fuel injection pressure is $100 \mathrm{MPa}$.

When developing the working process on a $116 \mathrm{~kW}$ diesel engine, three sets of hydromechanical injectors were used:
- injectors VA70P360 with DOP147P528 nozzles $\left(\mu \mathrm{f}=0.22 \mathrm{~mm}^{2}\right.$ ) (Motorpal, Czech Republic) (Fig. 5.a) (for an open combustion chamber);

- injectors AZPI 172.1112010-11.01 with nozzles AZPI 172.1112110-12.01 $(\mu \mathrm{f}=0.23 \ldots$ $0.25 \mathrm{~mm}^{2}$ );

- injectors VA70P360 with sac-less nozzles DOP140P528 ( $\left.\mu \mathrm{f}=0.18 \ldots 0.2 \mathrm{~mm}^{2}\right)$ (Motorpal, Czech Republic) (Fig. 5.b).

Matching of the combustion chamber form and the location of the fuel flares were coordinated using 3D models [20, 23]. The meeting points of the axes of the fuel jets with the walls of the combustion chamber are shown in Fig. 6 .

\section{Experimental research}

The comparative tests (results in table 1) for the NRSC cycle showed the possibility of achieving emission standards for Stage 3A.

The use of sac-less nozzles led to a decrease in fuel leakage and, as a consequence, to a decrease in nozzles coking, soot and $\mathrm{CH}_{\mathrm{x}}$ hydrocarbons emissions $[12,28]$.

Tests of the D-260.4S3A diesel engine with direct-acting fuel equipment showed a high exhaust smoke level while ensuring the target $\mathrm{NO}_{\mathrm{x}}$ emissions (table 1) using the EGR. As a result, achieving the Stage3A level for particulate emissions on a D-260.4 engine with a directacting fuel system with semi-open and open combustion chambers is not possible at this stage. Therefore, the proposed use of the type Low Cost "Common Rail" accumulator system. 


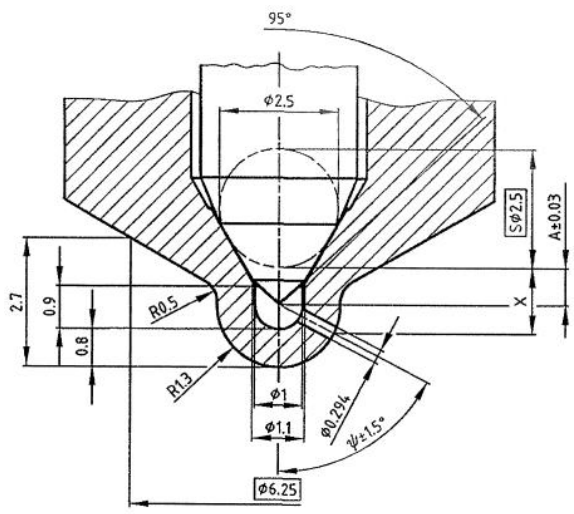

a

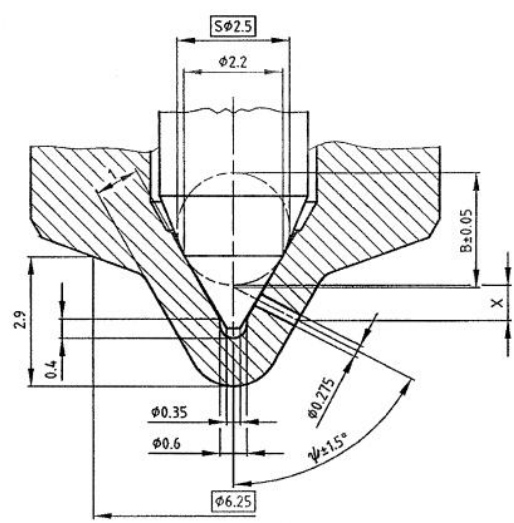

b

Fig. 5. Nozzle cone shapes: a - with a blind-hole (with a dead volume); $b$ - with the exit of nozzle holes to the surface of the locking cone (sac-less nozzle)

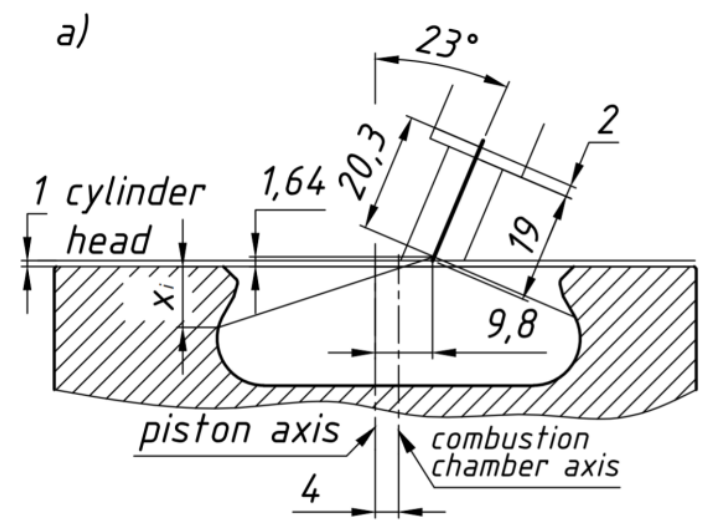

(3) Top view
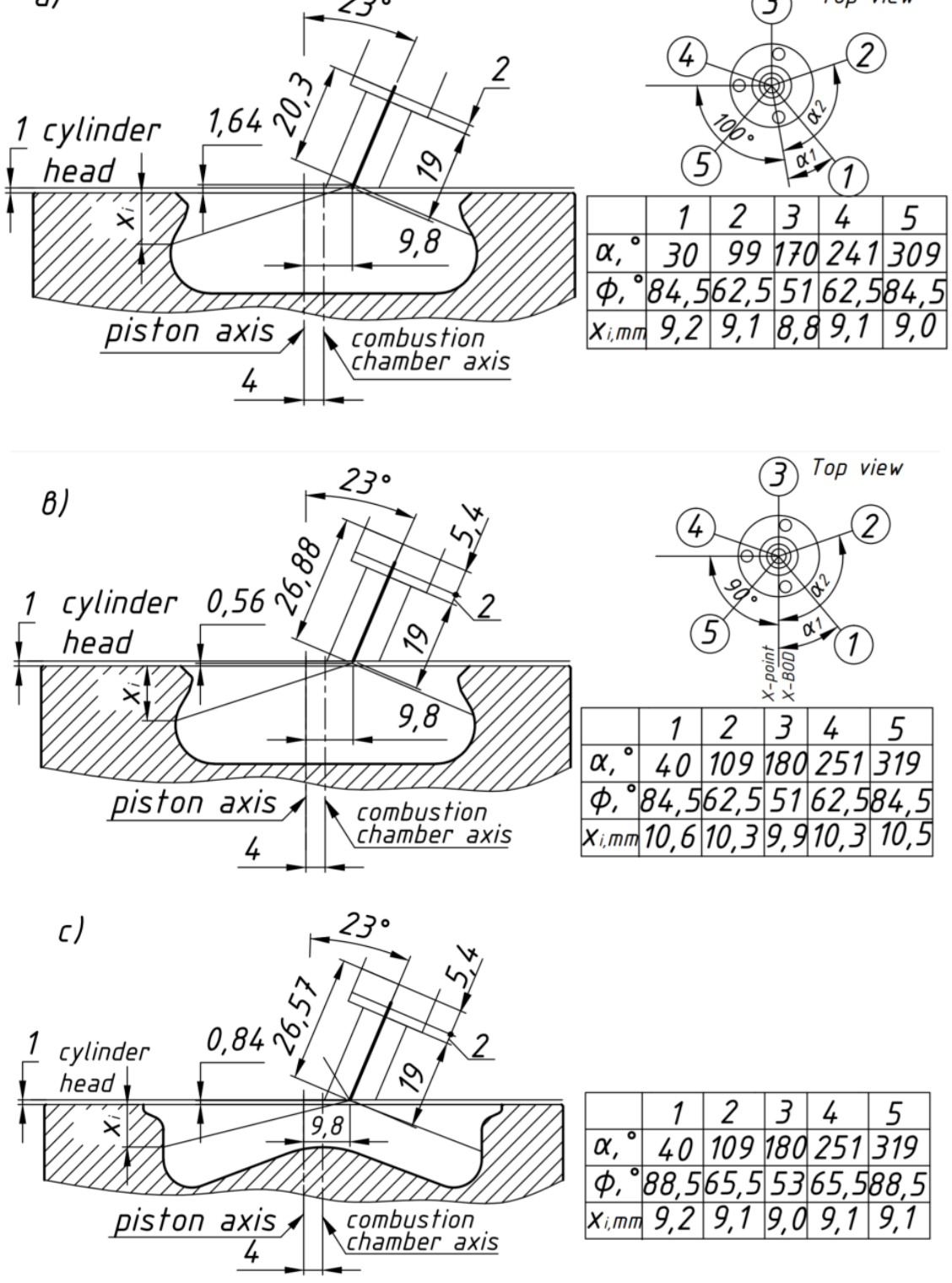

\begin{tabular}{|c|c|c|c|c|c|}
\hline & 1 & 2 & 3 & 4 & 5 \\
\hline$\alpha,{ }^{\circ}$ & 40 & 109 & 180 & 251 & 319 \\
\hline$\phi,{ }^{\circ} 88,5$ & 65,5 & 53 & $65,588,5$ \\
\hline$x_{i, \text { mm }}$ & 9,2 & 9,1 & 9,0 & 9,1 & 9,1 \\
\hline
\end{tabular}

Fig. 6. Determination of the points of intersection of the fuel flames axes with the combustion chambers walls: a - AZPI 172.1112110-12.01 nozzle; b - Motorpal DOP140P528; c - Motorpal DOP147P528 
Table 1 - Results of D-260.1 and D-260.4 diesel engines comparative tests with various nozzles and combustion chambers according to the NRSC cycle

\begin{tabular}{|c|c|c|c|c|c|c|c|c|}
\hline 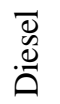 & Options & $\underset{\mathrm{g} /(\mathrm{kW} \cdot \mathrm{h})}{\mathrm{g}_{\mathrm{CH}},}$ & $\underset{\mathrm{g} /(\mathrm{kW} \cdot \mathrm{h})}{\mathrm{g}_{\mathrm{NOx}}}$ & $\begin{array}{c}\mathrm{g}_{\mathrm{SC}} \\
\mathrm{g} /(\mathrm{kW} \cdot \mathrm{h})\end{array}$ & $\begin{array}{c}\mathrm{g}_{\mathrm{eRP}} \\
\mathrm{g} /(\mathrm{kW} \cdot \mathrm{h})\end{array}$ & $\begin{array}{c}\mathrm{g}_{\text {eTmax }}, \\
\mathrm{g} /(\mathrm{kW} \cdot \mathrm{h})\end{array}$ & $\begin{array}{c}\mathrm{N}_{\mathrm{RP}} \\
\% \mathrm{HSU}\end{array}$ & $\begin{array}{l}\mathrm{N}_{\text {Tmax }}, \\
\% \text { HSU }\end{array}$ \\
\hline \multirow{3}{*}{ 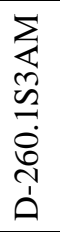 } & $\begin{array}{l}\text { Nozzles } \\
\text { AZPI 172.1112110-12.01 }\end{array}$ & 0,48 & 3,43 & 0,240 & 228,4 & 204,9 & 7,9 & 9,1 \\
\hline & \begin{tabular}{|l|} 
Nozzles \\
DOP140P528 \\
\end{tabular} & 0,21 & 3,84 & 0,164 & 229,9 & 204,5 & 6,6 & 4,3 \\
\hline & UNECE Regulation No. 96 (02) & \multicolumn{2}{|c|}{$4,0\left(\mathrm{NO}_{\mathrm{x}}+\mathrm{CH}\right)$} & 0,3 & \multicolumn{4}{|c|}{-} \\
\hline \multirow{3}{*}{ 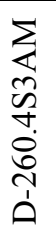 } & $\begin{array}{l}\text { Nozzles } \\
\text { DOP140P528 }\end{array}$ & - & 3,42 & 0,360 & 229,3 & 215,6 & 16,5 & 17,8 \\
\hline & $\begin{array}{l}\text { Nozzles DOP147P528, } \\
\text { open combustion chamber }\end{array}$ & - & 3,46 & 0,338 & 229,2 & 216,0 & 12,8 & 17,6 \\
\hline & UNECE Regulation No. 96 (02) & \multicolumn{2}{|c|}{$4,0\left(\mathrm{NO}_{\mathrm{x}}+\mathrm{CH}\right)$} & 0,2 & \multicolumn{4}{|c|}{-} \\
\hline
\end{tabular}

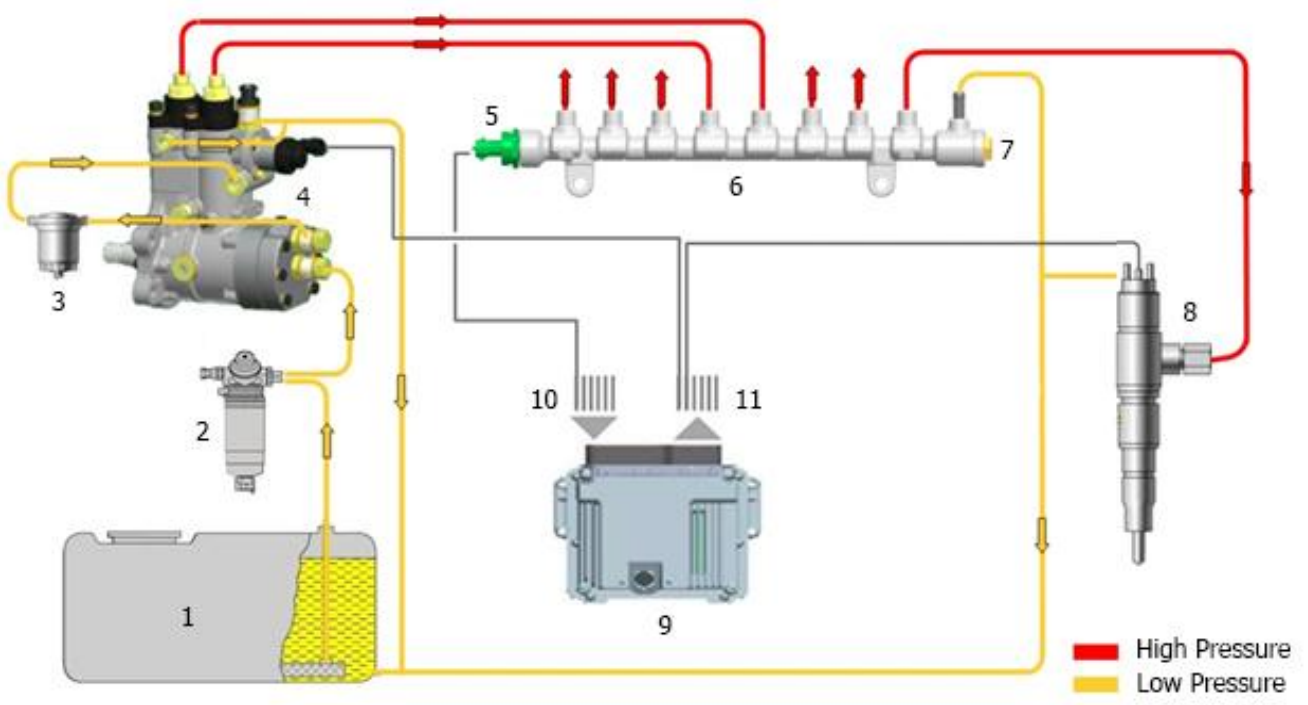

Fig. 7. Diagram of the common rail fuel system: 1 - fuel tank; 2 - coarse filter; 3 - fine filter; 4 - fuel pump; 5 - fuel pressure sensor; 6 - fuel rail; 7 - pressure-relief valve; 8 -injector; 9 - electronic control unit; 10 - signals from sensors; 11 - signals to actuators

The schematic diagram of "Common Rail" type Low Cost is shown in fig. 7. It consists of:

- fuel pump CB 28;

- injectors CRIN2 with 7-hole nozzles with a tent opening angle $\delta=147.6^{\circ}$ and a flow of 500 $\mathrm{cm} 3 / 30 \mathrm{~s}$ at a pressure of $100 \mathrm{bar}$,

- pressure accumulator LWRN18 with a maximum injection pressure of $1400 \mathrm{bar}$;

- the control unit EDC17CV54 with software version P_1142.3.0.0 for Low Cost system.

To increase the reliability of the units, the recirculation and turbocharging systems, they switched to a high-pressure recirculation system, the diagram of which is shown in Fig. 8 [22, 25, 26]. In the high-pressure EGR system, the recirculated exhaust gases do not pass through the turbocharging units, which should have a posi- tive effect on the operating conditions of the charge air cooler and compressor.

Tests of six-cylinder diesel engines with the high-pressure EGR system showed the problem of organization the EGR gas flow into the right direction. In some operating modes, the charge air pressure is higher than the exhaust pressure upstream the turbine. To create the necessary pressure difference, an additional rotary valve was introduced into the recirculation system, which prevents the free passage of exhaust to the turbine. As a result of testing a diesel engine with a Low Cost type Common Rail system and the rotary EGR valve, the rotary valve positions were determined and turbocharging units were selected to achieve Stage3A level for exhaust emissions. The test results of the engine D-260.4S3A are shown in table 2. 


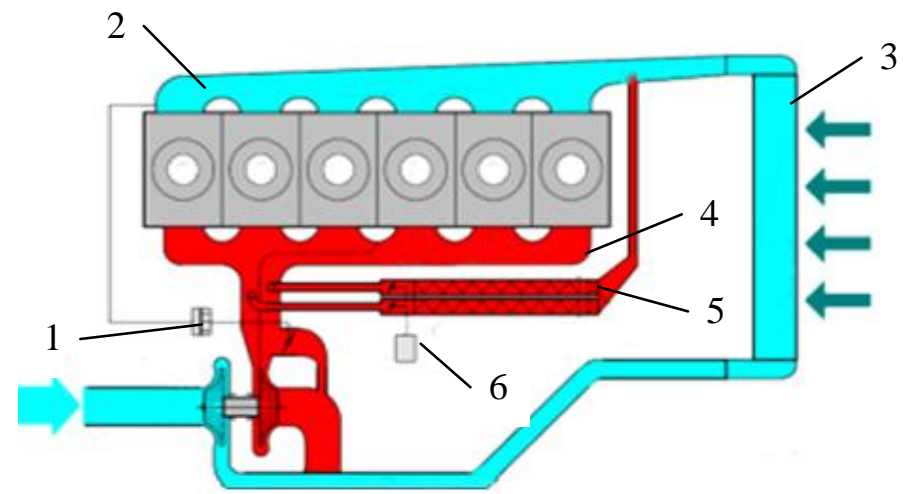

Fig. 8. Schematic diagram of the high-pressure EGR system: 1 - bypass valve; 2 - inlet manifold; 3 charge air cooler; 4 - exhaust manifold; 5 - EGR cooler; 6 - rotary EGR valve

Table 2 - Results of D-260.4S3A diesel tests with a common rail fuel system on the NRSC cycle

\begin{tabular}{|c|c|c|c|c|c|c|c|c|c|c|}
\hline \multirow{2}{*}{\multicolumn{2}{|c|}{ Parameters }} & \multicolumn{8}{|c|}{ Cycle Point } & \multirow{2}{*}{$\begin{array}{c}\text { Per } \\
\text { Cycle }\end{array}$} \\
\hline & & 1 & 2 & 3 & 4 & 5 & 6 & 7 & 8 & \\
\hline \multicolumn{2}{|l|}{ n. rpm } & 2100 & 2100 & 2100 & 2100 & 1600 & 1600 & 1600 & 800 & - \\
\hline \multicolumn{2}{|l|}{$\mathrm{M}_{\mathrm{K}} \cdot \mathrm{N} \cdot \mathrm{m}$} & 706 & 530 & 353 & 71 & 899 & 690 & 460 & 0 & - \\
\hline \multicolumn{2}{|l|}{$\alpha_{\text {EGRvalve }} \%$ op. } & 35 & 80 & 80 & 100 & 65 & 85 & 82 & 100 & - \\
\hline \multicolumn{2}{|l|}{$\mathrm{g}_{\mathrm{e}} \cdot \mathrm{g} /(\mathrm{kW} \cdot \mathrm{h})$} & 220.5 & 227.1 & 243.4 & 472.6 & 221.7 & 219.7 & 227.9 & - & - \\
\hline \multicolumn{2}{|l|}{ N. \%HSU } & 5.7 & 5.7 & 3.9 & 0.8 & 7.2 & 6.8 & 7.2 & 0.6 & - \\
\hline \multicolumn{2}{|l|}{$\mathrm{g}_{(\mathrm{NOx})} \cdot \mathrm{g} /(\mathrm{kW} \cdot \mathrm{h})$} & 4.61 & 2.57 & 2.00 & 3.25 & 4.39 & 2.47 & 1.69 & - & 3.30 \\
\hline \multicolumn{2}{|l|}{$\mathrm{g}_{(\mathrm{SC})} \cdot \Gamma /(\mathrm{KBT} \cdot \mathrm{q})$} & 0.136 & 0.146 & 0.111 & 0.031 & 0.148 & 0.141 & 0.168 & - & 0.138 \\
\hline \multirow{2}{*}{$\begin{array}{l}\text { UNECE Regu- } \\
\text { lation } \\
\text { No. 96(02) }\end{array}$} & $\mathrm{g}_{(\mathrm{NOx}+\mathrm{CH})} \cdot \mathrm{g} /(\mathrm{kW} \cdot \mathrm{h})$ & \multicolumn{8}{|c|}{-} & 4.0 \\
\hline & $\mathrm{g}_{(\mathrm{SC})} \cdot \mathrm{g} /(\mathrm{kW} \cdot \mathrm{h})$ & \multicolumn{8}{|c|}{-} & 0.2 \\
\hline
\end{tabular}

\section{Conclusions}

Measures have been developed to organize the working process of six-cylinder tractor diesel engines of ecological level Stage 3A with exhaust gas recirculation along the high-pressure circuit.

It has been established that the achievement of emission standards for harmful substances on diesel engines with a capacity of $116 \mathrm{~kW}$ is possible with the use of direct-action fuel equipment and a semi-open combustion chamber. Achieved total nitrogen oxides and unburned hydrocarbon emissions of $3.91 \mathrm{~g} /(\mathrm{kWh}) .2 \%$ less than the adopted Stage 3A emission level.

To meet Stage 3A standards on $156 \mathrm{~kW}$ diesel engines. it is necessary to use the Low Cost Common Rail fuel supply system and an open combustion chamber.

\section{Reference}

1. http://www.pommz.minsk.by/ catalogue/ applicability/

2. Севиздрал С.П. (2013). Состояние вопроса и перспективы развития двигателестроения в Республике Беларусь. № 6 (83). С. 6-7. Sevizdral S. P. (2013). Sostoyanie voprosa i perspektivy razvitiya dvigatelestroeniya $\mathrm{V}$ Respublike Belarus' [State of the issue and prospects for the development of engine building in the Republic of Belarus] Zhurnal associacii avtomobil'nyh inzhenerov. 6 (83). 6-7. [in Russian].

3. О безопасности сельскохозяйственных и лесохозяйственных тракторов и прицепов к ним ТР ТС 031/2012: принят 20.07.2012 : вступ. в силу 19.08.2012. Евраз. экон. комис. Минск : Экономэнерго. 2012. 60 с. О bezopasnosti sel'skohozyajstvennyh i lesohozyajstvennyh traktorov $\mathrm{i}$ pricepov $\mathrm{k}$ nim TR TS $031 / 2012$ : prinyat 20.07.2012 : vstup. v silu 19.08.2012 [On the safety of agricultural and forestry tractors and trailers to them TR CU 031/2012] Evraz. ekon. komis. Minsk : Ekonomenergo. 2012. [in Russian].

4. Правила ЕЭК ООН № 96 (02) (пересмотр 1) Единообразные предписания. касающиеся двигателей с воспламенением от сжатия. предназначенных для установки на сельскохозяйственных и лесных тракторах и внедорожной технике. в отношении выброса вредных веществ этими двигателями. Pravila EEK OON № 96 (02) (peresmotr 1) Edinoobraznye predpisaniya. kasayushchiesya dvigatelej s vosplameneniem ot szhatiya. prednaznachennyh dlya ustanovki na sel'skohozyajstvennyh i lesnyh traktorah i vnedorozhnoj tekhnike. $\mathrm{v}$ otnoshenii vybrosa vrednyh veshchestv etimi dvigatelyami [UNECE 
Regulation No. 96 (02) (revision 1) Uniform provisions for compression-ignition engines for agricultural and forestry tractors and off-road equipment with regard to the emission of harmful substances from these engines] [in Russian].

5. Basshuysen R., Schäfer F. (2015). Handbuch Verbrennungsmotor. Grundlagen. Komponenten. Systeme. Perspektiven. 7. Auflage. Wiesbaden : Vieweg \& Sohn Verlag. 1279 p.

6. Парсаданов И. В. (2003). Повышение качества и конкурентоспособности дизелей на основе топливно-экологического критерия. Харьков : Изд. центр НТУ «ХПИ». Parsadanov. I. V. (2003). Povyshenie kachestva i konkurentosposobnosti dizelej na osnove toplivno-ekologicheskogo kriteriya. [Improving the quality and competitiveness of diesel engines based on the fuel and environmental criterion] Har'kov : Izd. centr NTU «HPI». [in Russian].

7. Гаврилов П., Зарипов Р. Ю., Карку А. Д., Серикпаев Т. М. (2019) Методы снижения токсичности отработавших газов. Наука и техника Казахстана.- №1. - С. 75-85. Gavrilov P., Zaripov R. YU., Karku A. D., Serikpaev T. M. (2019) Metody snizheniya toksichnosti otrabotavshih gazov [Methods to reduce the toxicity of exhaust gases of a diesel engine]. Nauka i tekhnika Kazahstana. - 2019. - №1. - S. 75-85. [in Russian].

8. D.W. Jia, Xiwen Deng, J.L. Lei (2019) Intake flow interference analysis of combination intake port in diesel engine. Journal of Applied Fluid Mechanics. - Issue 12. - P. 61-67.

9. Системы управления дизельными двигателями: Перевод с немецкого: редкол.: В. В. Аверкиев [и др.]. Москва : Изд-во «За рулем» (2004). 480 c. Sistemy upravleniya dizel'nymi dvigatelyami [Diesel engine control systems]: Perevod s nemeckogo: redkol.: V. V. Averkiev [i dr.]. Moskva : Izd-vo «Za rulem» [in Russian].

10. Кухаренок Г. М., Березун В. И. (2018). Влияние параметров топливоподачи и рециркуляции отработавших газов на выбросы вредных веществ дизельных двигателей. Автомобільний транспорт. № 42. С. 5-11. Kuharenok G. M., Berezun V. I. (2018) Vliyanie parametrov toplivopodachi i recirkulyacii otrabotavshih gazov na vybrosy vrednyh veshchestv dizel'nyh dvigatelej [Influence of parameters of fuel supply and recirculation of exhaust gases on emissions of harmful substances of diesel engines]. Avtomobil'nij transport. 42. 511. [in Russian].

11. Shatrov M. G, Malchuk V. I., Dunin A. Y. [and others] (2018) A control method of fuel distribution by combustion chamber zones and its dependence on injection conditions. Thermal Science. - Volume 22, number 5. - P. 1425-1434.

12. Кухаренок Г. М., Клессо М. А., Предко А. В. (2020). Профилирование впускного канала малогабаритного дизеля. Актуальные вопросы машиноведения: Сборник научных трудов.
Выпуск 9. Минск. С. 79-83. Kuharenok G. М., Klesso M. A., Predko A. V. (2020). Profilirovanie vpusknogo kanala malogabaritnogo dizelya. Aktual'nye voprosy mashinovedeniya [Intake channel profiling of a small-sized diesel engine. Topical issues of mechanical engineering]: Sbornik nauchnyh trudov. Vypusk 9. Minsk. 7983 [in Russian].

13. Sahil Wahi, Sahib Singh (2020) Design and analysis of intake manifold of single cylinder engine. International Journal of Engineering Research \& Technology (IJERT). - Vol. 5, Issue 11. P. 107-123.

14. Meskhi B. Golev B. Efros V. [and others] Influence of parameters and location of the tumble inlet porton air charging in the diesel cylinder // Innovative Technologies in Environmental Science and Education (ITESE-2019), Divnomorskoe village, Russian Federation, Edited by Rudoy, D.; Murgul, V.; E3S Web of Conferences, Volume 135 , id. 01083.

15. Lakshminarayanan P. A., Avinash Kumar Agarwal (2019) Design and Development of Heavy Duty Diesel Engines. Springer. 930 p.

16. Алямовский А. А., Собачкин А. А., Одинцов Е. В., Харитонович А. И., Пономарев Н. Б. (2005). SolidWorks. Компьютерное моделирование в инженерной практике. СанктПетербург: БХВ-Петербург. 800 с. Alyamovskij A. A., So-bachkin A. A., Odincov E. V., Haritonovich A. I., Ponomarev N. B. (2005). SolidWorks. Komp'yuternoe modelirovanie $\mathrm{v}$ inzhenernoj praktike [SolidWorks. Computer modeling in engineering practice]. Sankt-Peterburg: BHV-Peterburg. [in Russian].

17. Дейч М. Е. (1969). Техническая газодинамика. Москва : Энергия. 368 с. Dejch. М. Е. (1969). Tekhnicheskaya gazodinamika [Technical gas dynamics]. Moskva : Energiya. [in Russian].

18. Kunjan Sanadhya, Gokhale N. P., Deshmukh B. S., Kumar M. N., Hulwan D. B. (2015) Effect of Helix Parameter Modification on Flow Characteristics of CIDI Diesel Engine Helical Intake Port // International Journal of Innovative Research in Science, Engineering and Technology. Vol. 4, Issue 4. - P. 2260-2271.

19. Кухаренок Г. М., Петрученко А. Н., Березун В. И. (2014). Выбор формы камеры сгорания дизельного двигателя. Віснік СевНТУ. № 1 (152). С. 65-68. Kuharenok G. M., Petruchenko A. N., Berezun V. I. (2014). Vybor formy ka-mery sgoraniya dizel'nogo dvigatelya [The choice of the shape of the combustion chamber of a diesel engine] Visnik SevNTU. 1(152). 65-68. [in Russian].

20. Кухаренок Г. М., Гершань Д. Г. (2011). Моделирование характеристик топливных струй и параметров камеры сгорания дизеля. Вестник БНТУ. № 4. С. 35-39. Kuharenok G. M., Gershan' D. G. (2011). Modelirovanie harakteristik toplivnyh struj i parametrov kamery 
sgoraniya dizelya [Modeling the characteristics of fuel jets and parameters of the combustion chamber of a diesel engine]. Vestnik BNTU. 4. 35-39 [in Russian].

21. Кухаренок Г. М., Березун В. И. (2014). Выбор формы камеры сгорания дизельного двигателя с низкой интенсивностью впрыска. Совершенствование организации дорожного движения и перевозок пассажиров и грузов. Минск : БНТУ. С. 180-184. Kuharenok G. M., Berezun V. I. (2014). Vybor formy kamery sgoraniya dizel'nogo dvigatelya s nizkoj intensivnost'yu vpryska. Sovershenstvovanie organizacii dorozhnogo dvizheniya i perevozok passazhirov i gruzov. [The choice of the shape of the combustion chamber of a diesel engine with a low injection rate. Improving the organization of road traffic and transportation of passengers and goods] Minsk : BNTU. 180-184. [in Russian].

22. Кухаренок Г. М., Березун В. И. (2018). Влияние параметров топливоподачи и рециркуляции отработавших газов на выбросы вредных веществ дизельных двигателей. Автомобільний транспорт. № 42. С. 5-11. Kuharenok G. M., Berezun V. I. (2018). Vliyanie parametrov toplivopodachi i recirkulyacii otrabotavshih gazov na vybrosy vrednyh veshchestv dizel'nyh dvigatelej. [Influence of parameters of fuel supply and recirculation of exhaust gases on emissions of harmful substances of diesel engines] Avtomobil'nij transport. 42. 511. [in Russian].

23. Petrov L. M., Borisenko T. N. (2017) Improvement of the combustion process of diesel engine fuel. Праці Одеського політехнічного університету. Вип. 2(52). - С. 24-28. Petrov L. M., Borisenko T. N. (2017) Improvement of the combustion process of diesel engine fuel. Praci Odes'kogo politekhnichnogo universitetu. Vip. 2(52). - S. 24-28.

24. Грехов. Л. В., Иващенко Н. А., Марков В. А. (2004). Топливная аппаратура и системы управления дизелей: Учебник для вузов. Москва: Легион-Автодата. 344 с. Grekhov L. V., Ivashchenko H. A., Markov V. A. (2004). Toplivnaya apparatura i sistemy upravleniya dizelej [Fuel equipment and diesel control systems] Uchebnik dlya vuzov. Moskva: LegionAvtodata. [in Russian].

25. Yang Z., Winward E., O'Brien G., Stobart R., et al. (2016) Modelling the Exhaust Gas Recirculation Mass Flow Rate in Modern Diesel Engines. SAE Technical Paper 2016-01-0550, doi: 10.4271/2016-01-0550.

26. Березун В. И. (2014). Исследование способов организации рециркуляции отработавших газов. Наука - образованию, производству, экономике : материалы 12 Междунар. науч.-техн. конф. Минск, 15 апр. 2014 г. : в 4 ч. / Белорус. нац. техн. ун-т ; редкол. : Б. М. Хрусталев [и др.]. - Минск. Ч. 2. - С. 56-57. Berezun V. I. (2014) Issledovanie sposobov organizacii recirkulyacii otrabotavshih gazov [Investigation of ways to organize exhaust gas recirculation]. Nauka - obrazovaniyu. proizvod-stvu. ekonomike : materialy 12 Mezhdunar. nauch.-tekhn. konf. Minsk, 15 apr. 2014 g. : v 4 ch. Belorus. nac. tekhn. un-t ; redkol. : B. M. Hrustalev [i dr.]. Minsk. CH. 2. 56-57. [in Russian].

Heorhi Kukharonak ${ }^{1}$, professor, Doct. of Science, Department of Internal Combustion Engines, tel. (+375)17-293-95-86, e-mail: kux@tut.by Alexander Petruchenko ${ }^{2}$, assistant professor. PhD of Science. senior scientist, tel. (375)17-218-3034, e-mail: MMZ.UGK.NS@yandex.by

Andrei Predko ${ }^{2}$, senior scientist, tel. (375)17-218-30-34, e-mail: MMZ.UGK.NS@yandex.by Dmitry Telyuk ${ }^{2}$, design engineer, tel. (375)17-218-30-34, e-mail: MMZ.UGK.KBRP@yandex.ru

${ }^{1}$ Belarussian National Technical University, 220013, Minsk, Nezavisimosty Ave, 65, Belarus.

${ }^{2}$ The OJSC "Minsk Motor Plant" Holding Managing Company, 220070, Minsk, Vaupshasov Str., 4, Belarus.

\section{Забезпечення екологічних норм Stage3A шестициліндровим тракторним дизелем} Анотація. Проблема. Стратегія розвитку Мінського моторного заводу, що реалізується в межах заводських і державних науково-технічних програм, спрямована на виготовлення конкурентоспроможної продукції, яка відповідає сучасним технічним вимогам міжнародних стандартів і якості. Обов'язковою умовою успішного просування дизелів на ринку позашляхової техніки є забезпечення необхідних екологічних показників за умови низької витрати палива й невисокої вартості двигуна. Відомі технічні рішення, спрямовані на досягнення екологічних показників рівня Stage3A, істотно підвищують вартість дизелів. Тому досягнення необхідних екологічних норм без значного подорожчання двигунів можна вважати актуальним завданням. Мета. Забезпечення екологічних норм Stage3A шестициліндровим тракторним дизелем. Методологія. Експериментальні дослідження проводилися для дизелів, укомплектованих акумуляторною системою подачі палива Common Rail BOSCH із тиском упорскування 140 МПа, форсунками, що мають сім соплових отворів; системою подачі палива безпосередньої дії з паливним насосом MOTORPAL, що забезпечує максимальний тиск упорскування 100 МПа, форсунками MOTORPAL i AЗПI 3 п'ятьма сопловими отворами; камерами згоряння двох типів 3 діаметрами горловин 55 і 67,5 мм; головками блока циліндрів. що забезпечують вихрові відношення 3-4 і 3,5-4,5; системою рециркуляції відпрацьованих газів по контуру високого тиску. Випробування проводилися по характерних точках циклу NRSC на трьох частотах обертання колінчастого вала: мінімального холостого 
ходу 800 хв$^{-1}$, максимального крутного моменту $1600 \mathrm{xB}^{-1}$ і максимальної потужності $2100 \mathrm{xB}^{-1}$. Результати. Встановлено, що досягнення норм викидів шкідливих речовин Stage $3 \mathrm{~A}$ на дизелях потужністю 116 кВт можливе 3 використанням паливної апаратури безпосередньої дії та 3 напіввідкритою камерою згоряння, на дизелях потужністю 156 кВт з використанням системи подачі палива «Common Rail» типу Low Cost i з відкритою камерою згоряння. Наукова новизна. Результати вибору форми камери згоряння, параметрів паливоподавальної апаратури, вихрового відношення впускних каналів, фаз газорозподілу й параметрів системи рециркуляції відпрацьованих газів, що дозволяють організувати протікання робочого процесу дизеля екологічного рівня Stage 3А. Практична значуцість. Розроблено й впроваджено на Моторному заводі елементи конструкції шестициліндрових дизелів.

Ключові слова: дизель, вихрове відночення, камера згоряння, система подачі палива, розпилювач палива.
Кухаренок Георгій Михайлович ${ }^{1}$. д.т.н., проф. кафедри двигунів внутрішнього згоряння, тел.: (+375)17-293-95-86, e-mail: kux@tut.by

Петрученко Олександр Миколайович ${ }^{2}$, доцент, к.т.н., с.н.с., тел.: (375)17-218-30-34, e-mail: MMZ.UGK.NS@yandex.by

Предко Андрій Володимирович ${ }^{2}$, с.н.с., тел.: (375)17-218-30-34,

e-mail: MMZ.UGK.NS@yandex.by

Телюк Дмитро Олександрович ${ }^{2}$, інженерконструктор, тел.: (375)17-218-30-34,

e-mail: MMZ.UGK.KBRP@yandex.ru

${ }^{1}$ Білоруський національний технічний університет, 220013, Республіка Білорусь, м. Мінськ, просп. Незалежності, 65.

${ }^{2}$ ВАТ «Управляюча компанія холдингу "Мінський моторний завод"», 220070, Республіка Білорусь, м. Мінськ, вул. Ваупшасова, 4. 